\title{
Correlation of lysosomal enzyme abnormalities in various forms of adult leukaemia
}

\author{
GTN BESLEY, SE MOSS, AD BAIN, AE DEWAR*
}

From the Department of Pathology, Royal Hospital for Sick Children and University of Edinburgh, Edinburgh EH9 ILF, and the *Department of Pathology, University of Edinburgh, Edinburgh EH8 $9 A G$

SUMMARY Lysosomal enzyme activities were studied in cells derived from the following types of leukaemia: chronic myeloid, acute myeloid, acute myelomonocytic, acute monocytic, non-T, non-B cell acute lymphoblastic, $\mathrm{T}$-cell acute lymphoblastic, B-cell chronic lymphocytic and $\mathrm{T}$-cell chronic lymphocytic. Activities of $\beta$-hexosaminidase and $\alpha$-mannosidase were significantly higher in cells from acute monocytic and acute myelomonocytic leukaemias, and somewhat higher in the other myeloid leukaemias, when compared with control granulocytes. Activities of $\beta$. bexosaminidase, $\alpha$-mannosidase, $\alpha$-fucosidase, $\beta$-glucuronidase and acid phosphatase were markedly lower in B cells of chronic lymphocytic leukaemia when compared with control or other leukaemic lymphoid cells. On isoelectric focusing abnormal patterns of $\beta$-hexosaminidase, $\alpha$ mannosidase and $\beta$-glucuronidase activities were commonly found in myeloid and non- $\mathrm{T}$, non- $\mathrm{B}$ cell leukaemias. All patients with acute myeloid leukaemia exhibited a relative decrease in the $B$ form of $\beta$-hexosaminidase activity. The results described show that studies on lysosomal enzymes may assist in the classification of different types of leukaemia.

Recognition of the leukaemic cell type is crucial to the diagnosis, management and prognosis of different types of the disease. In the leukaemias not only cell type but stage of differentiation must be assessed. Classification of the leukaemic cell has generally rested on its morphological, histochemical and immunological characteristics. ${ }^{1-3}$ Such studies may be complemented by the recognition of certain biochemical markers ${ }^{24}$ and specific activities of a number of enzymes including terminal deoxynucleotidyl transferase, adenosine deaminase and 5'nucleotidase may be helpful. Studies on lysosomal enzymes have been mainly cytoehemical and acid phosphatase $^{5}$ and $\alpha$-naphthyl acetate esterase ${ }^{6}$ may provide valuable $T$ cell markers. Quantitative assays of lysosomal enzyme activity may also produce useful data, although only limited reports have appeared so far. Low levels of $\beta$-hexosaminidase and $\beta$ glucuronidase activity have been reported ${ }^{7-9}$ in BCLL lymphocytes compared with normal or T-CLL lymphocytes. In other reports where activities of a number of lysosomal hydrolases were studied ${ }^{10} 11$ in cells from patients with different types of leukaemia various changes were noted, in particular high $\alpha$ -

Accepted for publication 6 April 1983 mannosidase activities in the non-lymphoid forms of leukaemia.

Previous studies on childhood lymphoblastic leukaemia have demonstrated abnormal patterns of $\stackrel{\mathbb{Q}}{\complement}$ lysosomal enzyme expression in non- $T$, non-B lym- $\overrightarrow{\vec{O}}$ phoblasts after enzyme separation by ion exchange 3 chromatography ${ }^{1213}$ or isoelectric focusing. ${ }^{14}$ Such $\rightleftharpoons$ subtle changes may also be expressed in adult forms of leukaemia and when combined with specific enzyme activities may significantly assist in cell classification. The present report is based on studies on $56 \frac{5}{3}$ adults with eight forms of leukaemia and it is suggested that such studies will assist in the classification of leukaemias.

\section{Material and methods}

Fifty-six adults were studied at presentation with various forms of leukaemia. Patients were classified o using standard histochemical and immunological $N$ techniques ${ }^{3}$ which included the following parameters: $N$ terminal deoxynucleotidyl transferase, Ia (HLA-Dr) antigen, sheep E "rosettes", non-specific esterase, acid phosphatase, chloroacetate esterase, and re- $\stackrel{0}{-}$ activity with the following monoclonal antibodies, $\stackrel{\Phi}{\oplus}$ OKT3, OKT4, OKT6, OKT8, OKM1 (Ortho-diagnostics Ltd) and $\mathrm{MO}_{2}$, J5 (Coulter Electronics Ltd). From these criteria patients were classified as $\mathbb{\mathbb { D }}$ 1000 
Table 1 Lysosomal enzyme activities in leukaemic and non-leukaemic cells (mean activities $\pm S D$ expressed as nmol/min per mg protein; No. of patients or control subjects are indicated in parentheses)

\begin{tabular}{|c|c|c|c|c|c|}
\hline Cell type & $\beta$-hexosaminidase & $\alpha$-mannosidase & quicosidase & $\beta$-glucuronidase & Acid phosphatase \\
\hline $\begin{array}{l}\text { Control } \\
\text { granulocytes } \\
\text { CML } \\
\text { AML } \\
\text { AMMOL } \\
\text { AMOL } \\
\text { Control }\end{array}$ & $\begin{array}{r}25 \cdot 4 \pm 5 \cdot 8(10) \\
43 \cdot 9 \pm 18 \cdot 7(5) \dagger \\
52 \cdot 4 \pm 26 \cdot 5(7) \dagger \\
124 \pm 40 \\
159 \pm 41 \quad(7)\end{array}$ & $\begin{array}{r}4 \cdot 6 \pm 1 \cdot 8(10) \\
14 \cdot 4 \pm 16 \cdot 1(5) \\
12.9 \pm 8 \cdot 8(7) \dagger \\
17 \cdot 1 \pm 14 \cdot 5(7) \dagger \\
16.9 \pm 3 \cdot 3(7)\end{array}$ & $\begin{array}{l}1.65 \pm 0.31(10) \\
1.49 \pm 1.12(5) \\
1.44 \pm 1.06(7) \\
2.39 \pm 1.99(7) \\
5.13 \pm 1.25(7)\end{array}$ & $\begin{array}{c}10.1 \pm 2 \cdot 7(10) \\
7 \cdot 1 \pm 3 \cdot 9(5) \\
7 \cdot 3 \pm 4 \cdot 0(7) \\
11 \cdot 1 \pm 3 \cdot 5(7) \\
17 \cdot 3 \pm 8 \cdot 3(7)\end{array}$ & $\begin{array}{l}34 \cdot 3 \pm 8 \cdot 9(10) \\
27 \cdot 3 \pm 8 \cdot 4(3) \\
21 \cdot 7 \pm 7 \cdot 5(3) \\
39 \cdot 1 \pm 9 \cdot 6(4) \\
42 \cdot 3 \pm 17 \cdot 4(7)\end{array}$ \\
\hline $\begin{array}{l}\text { lymphocytes } \\
\text { non-T, non-B ALL } \\
\text { B-CLL } \\
\text { T-CLL } \\
\text { T-ALL }\end{array}$ & $\begin{array}{l}29 \cdot 6 \pm 6 \cdot 6(5) \\
25 \cdot 4 \pm 15 \cdot 7(12) \\
12 \cdot 6 \pm 5 \cdot 8(12) \ddagger \\
23 \cdot 5 \pm 3 \cdot 9(3) \\
46 \cdot 3 \pm 28 \cdot 0(3)\end{array}$ & $\begin{array}{c}5 \cdot 5 \pm 1 \cdot 2(5) \\
1 \cdot 66 \pm 2 \cdot 20(12) 8 \\
0.61 \pm 0.38(12) \neq \\
1 \cdot 26 \pm 0.58(3) \\
1 \cdot 21 \pm 0.83(3)\end{array}$ & $\begin{array}{l}1 \cdot 46 \pm 0.17(5) \\
1 \cdot 10 \pm 0.80(12) \\
0.61 \pm 0.38(12) \mp \\
1 \cdot 13 \pm 0.32(3) \\
2 \cdot 30 \pm 1 \cdot 40(3)\end{array}$ & $\begin{array}{l}8.0 \pm 1.8(5) \\
2.94 \pm 1.62(12) \ddagger \\
3.57 \pm 1.93(12) \ddagger \\
4.0 \pm 0.5(3) \\
3.47 \pm 1.25(3)\end{array}$ & $\begin{array}{c}41 \cdot 5 \pm 9 \cdot 0(5) \\
7 \cdot 8 \pm 6 \cdot 3(10) \ddagger \\
15 \cdot 6 \pm 10.4(12) \ddagger \\
15 \cdot 1 \pm 7 \cdot 0(3) 8 \\
7 \cdot 1 \pm 4 \cdot 5(3) \ddagger\end{array}$ \\
\hline
\end{tabular}

Degrees of significance were evaluated by Student's $t$ test.

${ }^{*} \mathrm{p}<0.001$ compared with control granulocytes.

$+\mathrm{p}<0.01$ compared with control granulocytes.

$\ddagger \mathrm{p}<0001$ compared with control lymphocytes.

s $<<01$ compared with control lymphocytes.

follows: chronic myeloid leukaemia (CML) 5 cases; acute myeloid leukaemia (AML) 7 cases; acute myelomonocytic (AMMOL) 7 cases; acute monocytic (AMOL) 7 cases; non-T, non-B cell acute lymphoblastic (non-T, non-B ALL) 12 cases; $T$-cell acute lymphoblastic leukaemia (T-ALL) 3 cases; B-cell chronic lymphocytic leukaemia (B-CLL) 12 cases; T-cell chronic lymphocytic leukaemia (T-CLL) 3 cases.

Control leucocytes were separated from heparinised peripheral blood, using Ficoll-Paque sedimentation for lymphocytes ${ }^{15}$ and dextran (Dextraven 110, Fisons Ltd) sedimentation for granulocytes. Leukaemic cells were collected either by FicollPaque sedimentation or in lymphoblastic leukaemia and CML by sedimentation at $1 \mathrm{~g}$. Cells were washed twice with culture medium (TC 199, Flow Labs Ltd) and stored (up to 18 months) at $-70^{\circ} \mathrm{C}$ as cell pellets prior to analysis. Of the samples studied, 50 of 56 contained in excess of $70 \%$ leukaemic cells, 3 had > $60 \%$ and 3 had $>50 \%$.

Lysosomal enzyme activities were measured on sonicated cell extracts as reported earlier. ${ }^{14}$ Enzyme assays were carried out under optimal conditions using standard fluorogenic substrates in the form of 4-methylumbelliferone conjugates. Protein concentrations were determined as described earlier. ${ }^{14}$

Isoelectric focusing was carried out in a linear sucrose gradient containing Triton X $100(1 \mathrm{~g} / \mathrm{l})$ and ampholine (LKB Ltd) in the range $\mathrm{pH} 3 \cdot 5-10 .{ }^{14} \mathrm{Up}$ to six columns of $10 \mathrm{ml}$ working capacity could be run simultaneously and $\mathbf{4 0}$ fractions were collected from each column. The $\mathrm{pH}$ of each fraction was recorded immediately at $5^{\circ} \mathrm{C}$ and enzyme activities were measured as indicated above.

\section{Results}

Acid hydrolase activities of leukaemic and nonleukaemic cells are shown in Table 1 and Fig. 1. For all five enzymes, activities were similar $(p>0.01)$ in fully differentiated lymphocytes and granulocytes. However, significant differences were observed between many leukaemic cells and their mature counterparts. These differences were most clearly seen for $\beta$-hexosaminidase and $\alpha$-mannosidase activities (Fig. 1). Leukaemic cells of myeloid or monocytic origin displayed markedly higher activities of $\beta$-hexosaminidase and $\alpha$-mannosidase; for $\beta$ hexosaminidase the order was AMOL > AMMOL > AML $>$ CML $>$ granulocytes. Mean $\beta$-hexosaminidase activity of AMOL cells was more than fourfold higher than that $(35 \mathrm{nmol} / \mathrm{min}$ per $\mathrm{mg}$ protein) measured in mature monocytes from a single patient studied with acute monocytosis. With regard to lymphoid cells the most striking feature $(p<0.001)$ was the low activity of all hydrolases studied in B-CLL lymphocytes. In all acute and chronic lymphoid leukaemias studied, where patients were at presentation, $\alpha$-mannosidase activity was significantly ( $p<$ 0.01 ) reduced, lowest activity was associated with B-CLL lymphocytes.

On isoelectric focusing of control granulocyte extracts, $\beta$-hexosaminidase activity was resolved into two major peaks corresponding to component $\mathrm{A}$ ( $\mathrm{pI}$ $5 \cdot 2$ ) and component $B$ (pI 7.8) (Fig. 2). The size of the $\beta$-hexosaminidase $A$ peak was generally twice that of $\beta$-hexosaminidase $B$, mean ratio of peak heights being 2.0 units (Table 2 ). In all samples studied from patients with AML, the activity of the B component was markedly reduced (Table 2 ) giving a 

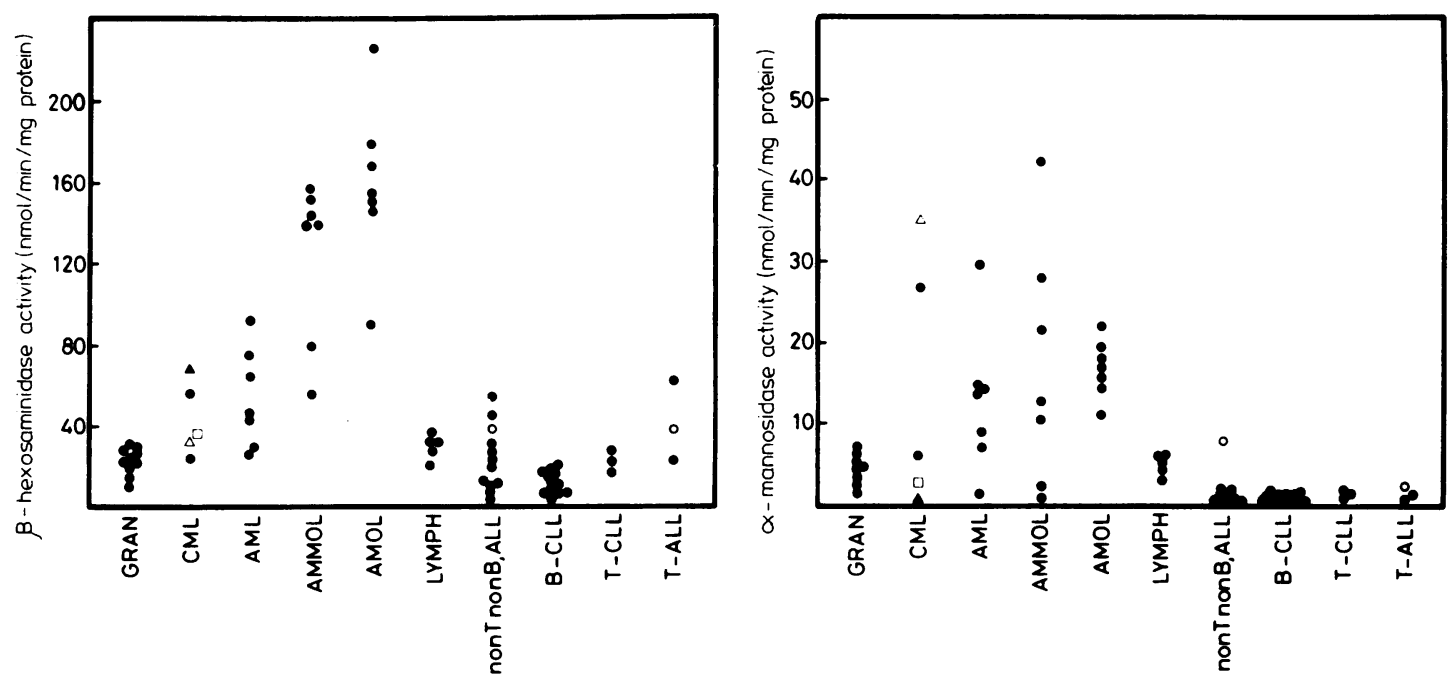

Fig. 1 Activities of $\beta$-hexosaminidase and $\alpha$-mannosidase in leukaemic and control cells. Activities in control leucocytes are indicated thus:

G RAN granulocytes; LYMPH lymphocytes; abbreviations for leukaemic cells are as indicated in Table I. Patients were at presentation ( $\bullet$ ) or relapse (o), and of the $C M L$ patients studied, one $(\Delta)$ was in myeloid blast crisis, one $(\triangle)$ in transformation and one ( $\square$ ) in lymphoid blast crisis.

mean ratio of $\beta$-hexosaminidase A peak height to that of $\beta$-hexosaminidase B of $7 \cdot 1$ units (range $3 \cdot 4-19 \cdot 0$ units) (see Table 2). Similar profiles were seen in 3/5 CML patients (mean ratio of all CML samples, 5.7 units), in 3/7 AMMOL patients (mean ratio of all AMMOL samples, 4.1 units) and in $2 / 7$ AMOL patients (mean ratio of all AMOL samples, $2 \cdot 5$ units). Abnormalities in $\beta$-hexosaminidase profiles in myeloid/monocytic cells were independent of specific activities. Enzyme profiles in mature monocytes have not yet been satisfactorily established.

For leukaemic lymphoid cells abnormalities of $\beta$ hexosaminidase profiles were exhibited in a different

Table 2 Ratio of $\beta$-hexosaminidase peak heights in nonlymphoid leukaemias. Activities determined after isoelectric focusing

\begin{tabular}{|c|c|c|c|c|}
\hline \multirow[t]{2}{*}{$\begin{array}{l}\text { Cell type or } \\
\text { source }\end{array}$} & \multirow[t]{2}{*}{$\begin{array}{l}\text { No of } \\
\text { samples }\end{array}$} & \multicolumn{2}{|c|}{$\begin{array}{l}\text { Ratio of A peak: } \\
\text { B peak }\end{array}$} & \multirow{2}{*}{$\begin{array}{l}\text { Frequency } \\
\text { of abnormal } \\
\text { profiles }\end{array}$} \\
\hline & & Mean value & Range & \\
\hline $\begin{array}{l}\text { Normal } \\
\text { granulocytes } \\
\text { CML* } \\
\text { AML } \\
\text { AMMOL } \\
\text { AMOL }\end{array}$ & $\begin{array}{r}10 \\
5 \\
7 \\
7 \\
7\end{array}$ & $\begin{array}{l}2 \cdot 0 \\
5 \cdot 7 \\
7 \cdot 1 \\
4 \cdot 1 \\
2 \cdot 5\end{array}$ & $\begin{array}{l}1 \cdot 6-2 \cdot 7 \\
1 \cdot 1-10 \cdot 4 \\
3 \cdot 4-19 \cdot 0 \\
1 \cdot 1-13 \cdot 0 \\
1 \cdot 0-8 \cdot 0\end{array}$ & $\begin{array}{l}0 / 10 \\
3 / 5 \\
7 / 7 \\
3 / 7 \\
2 / 7\end{array}$ \\
\hline
\end{tabular}

* Leukaemic cells derived from patients with the following leukaemias: chronic myeloid (CML), acute myeloid (AML), acute myelomonocytic (AMMOL), and acute monocytic (AMOL). fashion. In $4 / 12$ non- $T$, non-B ALL lymphoblas\& samples, intermediate peaks of $\beta$-hexosaminidase activity (see Fig. 2) were recognised. Similar patê. terns were also found in one adult T-ALL and one T-CLL patient (Table 3). Abnormal patterns of

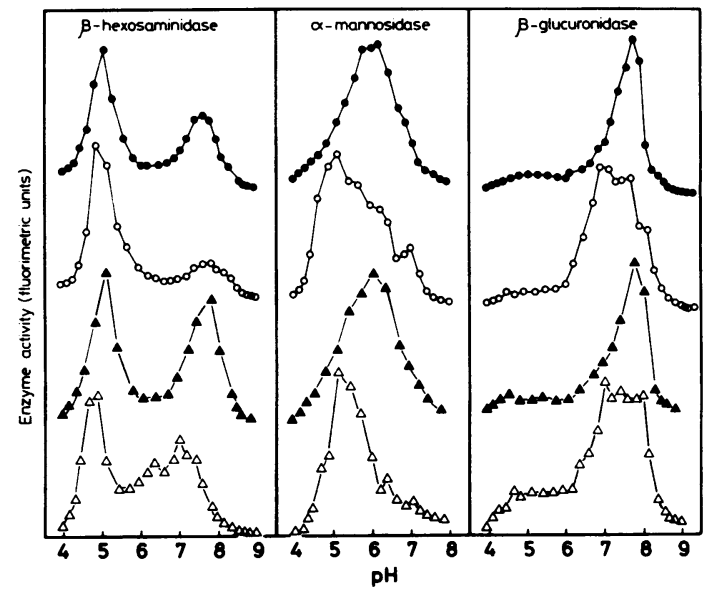

Fig. 2 Isoelectric focusing profiles of lysosomal enzyme activities in leukaemic and control cells. Activities of $\beta$-hexosaminidase (left), $\alpha$-mannosidase (centre) and $\beta$-glucuronidase (right) are plotted against fraction $\mathrm{pH}$ at $5^{\circ} \mathrm{C}$. Cell extracts were derived from control granulocytes $(\bullet)$, a patient with acute myeloid leukaemia ( 0$)$, control lymphocytes $(\Delta)$, and a patient with non- $T$, non-B cell acute lymphoblastic leukaemia $(\triangle)$. 
Table 3 Frequency of abnormal profiles of lysosomal enzyme activity in leukaemic cells. Activities were determined in fractions following isoelectric focusing

\begin{tabular}{|c|c|c|c|c|}
\hline \multirow{2}{*}{$\begin{array}{l}\text { Leukaemic } \\
\text { cell source* }\end{array}$} & \multicolumn{4}{|c|}{ Enzyme activity profile } \\
\hline & $\begin{array}{l}\beta \text {-hexo- } \\
\text { saminidase }\end{array}$ & $\begin{array}{l}\alpha \text {-man- } \\
\text { nosidase }\end{array}$ & $\begin{array}{l}\alpha \text {-fucosi- } \\
\text { dase }\end{array}$ & $\begin{array}{l}\text { } \text {-glucuroni- } \\
\text { dase }\end{array}$ \\
\hline $\begin{array}{l}\text { CML } \\
\text { AML } \\
\text { AMMOL } \\
\text { AMOL } \\
\text { non-T, non-B } \\
\text { ALL } \\
\text { T-ALL } \\
\text { T-CLL } \\
\text { B-CLL }\end{array}$ & $\begin{array}{l}4 / 12 \\
1 / 3 \\
1 / 3 \\
0 / 12\end{array}$ & $\begin{array}{l}4 / 12 \\
1 / 3 \\
0 / 3 \\
0 / 12\end{array}$ & $\begin{array}{l}0 / 12 \\
1 / 3 \\
0 / 3 \\
0 / 12\end{array}$ & $\begin{array}{l}5 / 12 \\
2 / 3 \\
0 / 3 \\
0 / 12\end{array}$ \\
\hline
\end{tabular}

*Cells were derived from patients with the following types of leukaemia:

chronic myeloid $(C M L)$, acute myeloid $(A M L)$, acute myelomonocytic (AMMOL), acute monocytic (AMOL), non-T, non-B cell acute lymphoblastic (non-T. non-B ALL). T-cell acute lymphoblastic (T-ÁLL). T-cell chronic lymphocytic (T-CLL). B-cell chronic Iymphocytic (B-CLI_)

$\alpha$-mannosidase and $\beta$-glucuronidase activity were commonly found in cells from patients with acute forms of both myeloid/monocytic and lymphoid leukaemia. as indicated in Table 3. The type of abnormality was similar in all cases (both myeloid and lymphoid types) and resulted in an apparent shift of enzyme activity to a more anodic position. For $\alpha$ mannosidase the major peak shifted from pI $6 \cdot 2$ to $\mathrm{pI}$ $5 \cdot 1$ and for $\beta$-glucuronidase the major peak shifted from pI 7.9 to pI 7.0 (Fig. 2). The most consistent changes were seen for AML patients where abnormal $\alpha$-mannosidase profiles were seen in $6 / 7$ patients, and abnormal $\beta$-glucuronidase profiles were found in $7 / 7$ patients. Activity profiles for $\alpha$-fucosidase were also studied in all cases; a normal profile was observed in all but one case (T-ALL patient) where the major enzyme shifted from pI $6 \cdot 2$ to $\mathrm{pI} 5 \cdot 2$, similar to the change observed for $\alpha$-mannosidase.

The abnormal expression of lysosomal enzyme profiles in these leukaemic patients did not appear to correlate with other markers studied nor with the clinical expression of the disease.

\section{Discussion}

Previous studies from this laboratory ${ }^{14}$ and elsewhere ${ }^{1213}$ have concentrated on patterns of lysosomal enzyme expression in acute forms of childhood lymphoblastic leukaemia. In the current report, studies have been extended to cover other forms of leukaemia in adults. Although cytochemical analyses of lysosomal enzyme activities ${ }^{56}$ are fairly widely used, quantitative assays which may complement these, have been less extensively studied. Studies on different populations of normal peripheral leucocytes ${ }^{16-18}$ have suggested that specific cells possess characteristic levels of hydrolase activity. Many lysosomal enzyme activities, including $\beta$ hexosaminidase, $\beta$-glucuronidase and acid phosphatase, but excluding $\alpha$-mannosidase, were found ${ }^{16}$ to be high in normal monocytes. In leukaemic monocytes activities were somewhat higher in one report ${ }^{10}$ but in our study activities, particularly of $B$ hexosaminidase and $\alpha$-mannosidase, were markedly raised. High $\alpha$-mannosidase activity in these cells may thus reflect a change associated with malignancy rather than a monocytic characteristic. A similar biochemical change associated with malignancy may occur in B-CLL lymphocytes. Compared with $\mathrm{T}$ lymphocytes, normal B lymphocytes have been reported ${ }^{1719}$ to possess slightly lower activities of $\beta$-hexosaminidase, $\beta$-glucuronidase and acid phosphatase but rather higher $\alpha$-mannosidase activities. Yet $\alpha$-mannosidase activity was markedly $(p<0.001)$ lower in B-CLL lymphocytes in our study, and others. ${ }^{119}$ Low activities of $\beta$-hexosaminidase and $\beta$-glucuronidase in B-CLL lymphocytes confirm previous biochemical ${ }^{711920}$ and cytochemical $^{820}$ analysis, although our findings would suggest a general depression of lysosomal activity in these cells, as suggested by EM studies.' Activities in TCLL lymphocytes were not depressed to the same extent in the three patients studied here and one elsewhere..$^{20}$ In all lymphoid leukaemias, apart from $\beta$-hexosaminidase, the activities of lysosomal enzymes were somewhat lower than those of control cells (Table 1); a similar finding has been reported by others. ${ }^{11}$

To characterise further the nature of lysosomal enzyme activity in leukaemic cells, enzyme components were separated by isoelectric focusing. It has been established ${ }^{1214}$ that intermediate forms of $\beta$ hexosaminidase activity are expressed in lymphoblasts of most (approx. 80\%) cases of childhood non-T, non-B ALL. In the current study intermediate components were identified in only one third of adults with non-T, non-B ALL (Table 3 ). No adults with B-CLL expressed abnormal enzyme patterns despite having significantly lowered enzyme activities. One patient with T-CLL had an abnormal $\beta$-hexosaminidase profile which was similar to the non-T, non-B ALL pattern. However in one T-ALL adult, all four hydrolase profiles were clearly abnormal; intermediate forms of $\beta$-hexosaminidase and anodic forms of $\alpha$-mannosidase (pI 4.9), $\alpha$-fucosidase (pI $5 \cdot 2$ ) and $\beta$-glucuronidase (pI 7.0) activities were present. This patient who was in relapse was classified as having T-ALL based on focal acid phosphatase activity, positive reactions with OKT3 and OKT6 and the presence of TdT at a level of 91 units $/ 10^{8}$ cells.

Anodic forms of $\alpha$-mannosidase were commonly 
found (Table 3 ) in acute leukaemias of both lymphoid or myeloid origin but not in the chronic leukaemias studied. These enzymes may therefore reflect a biochemical event associated with acute forms of malignancy in these cells rather than that of a specific cell marker. Previous studies ${ }^{13}$ failed to recognise abnormal $\alpha$-mannosidase profiles in three children with AML, although abnormal $\alpha$-mannosidase profiles were seen in those non-T, non-B ALL patients whose cells expressed intermediate $\beta$-hexosaminidase activity. In this study abnormal $\alpha$-mannosidase profiles in lymphoid leukaemias appeared identical to those in myeloid or monocytic forms of leukaemia.

Although intermediate forms of $\beta$-hexosaminidase were seen in some lymphoid leukaemias, these components were never found in the non-lymphoid leukaemias. But within this latter group, specific patterns of $\beta$-hexosaminidase expression were identified as a low B component compared with the A component (see Table 2). The nature of this abnormality is not known particularly since abnormal profiles did not correlate with specific activities. Precisely why lysosomal enzyme activities or patterns of expression are altered in leukaemia is not defined by these or other studies. However. lysosomal enzymes are glycoprotein in nature and a number of changes involving the oligosaccharide structure of glycoproteins ${ }^{2122}$ and glycolipids ${ }^{2324}$ have been associated with forms of malignancy and cellular differentiation. Lysosomal enzymes may undergo similar changes: for example, abnormal sialylation may result in altered isoelectric points of enzymes. Studies of lysosomal enzymes may therefore provide a useful means of studying oligosaccharide abnormalities associated with malignancy whilst at the same time provide useful enzyme markers in leukaemia.

We thank consultant haematologists at the following hospitals for samples from their patients: Royal Infirmary, Edinburgh; Western General, Edinburgh; Bangour General; Falkirk Royal Infirmary and Fife Area laboratories, Kirkcaldy. We thank Professor Sir Alastair Currie for his support and interest and the Haematology Department, Royal Infirmary, Edinburgh for Tdt estimations. We are grateful to the Cancer Research Campaign for financial support and one of us (AED) was supported by a grant to the Edinburgh Lymphoma Group.

\section{References}

' Greaves MF. Janossy G. Patterns of gene expression and the cellular origins of human leukaemias. Biochim Biophys Acta 1978;516:193-230.

2 Hoffbrand AV. Janossy G. Enzyme and membrane markers in leukaemia: recent developments. J Clin Pathol 1981;34:254-62.

' Maheu M, Baker MA, Falk JA, Taub RN. Immunologic diagnosis and monitoring of human acute leukemias. Am J Pathol 1981; 103:139-58.

4 Blatt J, Reaman G, Poplack DG. Biochemical markers in lymphoid malignancy. N Engl J Med 1980;303:918-22.

s Catovsky D. Cherci M. Greaves MF. Janossy G. Pain C. Kay HEM. Acid phosphatase reaction in acute lymphoblastic leukaemia. Lancet 1978;i:749-51.

- Pinkus GS, Hargreaves HK, McLeod JA, Nadler LM, Rosenthal DS, Said JW. $\alpha$-naphthyl acetate esterase activity - a cytochemical marker for T lymphocytes. Am J Pathol 1979:97: $17-41$.

' Douglas SD, Cohnen G, Konig E, Brittinger G. Lymphocyte lysosomes and lysosomal enzymes in chronic lymphocytic leukaemia lymphocytes. Blood 1973;41:511-8.

* Zittoun R. Cadiou M. Dao C. Blanc JM. Bousser J. Lymphocytic B-glucuronidase in the lymphoproliferative syndromes. Biomedicine 1973:18:415-20.

- Crockard AD, Lewis MHR, Bridges JM. N-acetyl-ß-Dglucosaminidase activity in normal and chronic lymphocytic lymphocytes. Clin Chim Acta 1979;93:151-6.

${ }^{10}$ Hultberg B, Sjogren V. Diagnostic significance of lysosomal enzymes in different types of leukaemia. Acta Med Scand 1980; 207: 105-10.

"Tanaka T. Kobayashi M. Saito O. Kamada N. Kuramoto A. Usui T. Biochemical activities of lysosomal acid hydrolases in leukaemic cells. Clin Chim Acta 1981;117:121-31.

12 Ellis RB, Rapson NT, Patrick AD, Greaves MF. Expression of hexosaminidase isoenzymes in childhood leukaemia. $N$ Engl J Med 1978;298:476-80.

${ }^{13}$ Dewji N, Rapson N, Greaves M, Ellis R. Isoenzyme profiles of lysosomal hydrolases in leukaemic cells. Leuk Res 1981;5: 19-27.

14 Broadhead DM, Besley GTN, Moss SE, Bain AD, Eden OB Sainsbury CPQ. Recognition of abnormal lysosomal enzyng patterns in childhood leukaemia by isoelectric focusing wity special reference to some properties of abnormally expresse components. Leuk Res 1981;5:29-40.

15 Boyum A. Isolation of mononuclear cells and granulocytes from human blood. Scand J Clin Lab Invest 1968;21 (suppl 97): 77-109.

${ }^{16}$ Beutler E, Kuhl W, Matsumoto F, Pangalis G. Acid hydrolases in leukocytes and platelets of normal subjects and in patients with Gaucher's and Fabry's diseases. J Exp Med 1976;143:975-80.

17 Pangalis GA, Kuhl W, Waldman SR, Beutler E. Acid hydrolases in normal B and T lymphocytes. Acta Haematol 1978;59:285-92.

is Tanaka.T. Biochemical activities of nine lysosomal enzymes in $\mathrm{T}$ and non-T lymphocytes. FEBS Lett 1979;104:161-4.

14 Kraaijenhagen RJ, Schipper-Kester GPM, Rijksen G, de Gast GC, Staal GEJ. Lysosomal enzymes in normal and leukaemic B lymphocytes. Clin Chim Acta 1982;118:255-63.

${ }^{20}$ Dempsey SI, Crockard AD, Bridges JM. An estimation of $\beta^{-}$ glucuronidase and $\mathrm{N}$-acetyl- $\beta$-D-glucosaminidase activity in 8 normal and chronic lymphocytic leukaemia lymphocytes. Acta Haematol 1980;64:141-7.

${ }^{21}$ Gahmberg CG, Andersson LC, Nilsson K. Surface glycoproteins of human non-T, non-B acute lymphocytic leukaemia cell lines. I Leuk Res 1980;4:279-86.

22 Rupar CA, Cook GMW. Glycoprotein biosynthesis in quiescent and stimulated thymocytes and a T-cell lymphoma. Biochem $J \mathrm{~N}$ 1982;201:377-85.

${ }^{23}$ Nakahara K, Ohashi T, Oda T, Hirano T, Kasai M, Okumura K, N Tada T. Asialo GM, as a cell surface marker detected in acute $\mathrm{N}$ lymphoblastic leukaemia. N Engl J Med 1980;302:674-7.

24 Lee WMF. Westrick MA, Macher BA. Neutral glycosphingolipids of human acute leukaemias. J Biol Chem 1982;257:0 10090-5.

Requests for reprints to: Dr GTN Besley, Department of Pathology, Royal Hospital for Sick Children, Edinburgh EH9 1LF, Scotland. 